\title{
PENGGUNAAN METODE PEMBELAJARAN KOOPERATIF TIPE STAD UNTUK MENINGKATKAN AKTIVITAS DAN HASIL BELAJAR SISWA
}

\author{
Mujazi \\ Fakultas Keguruan dan Ilmu Pendidikan, Universitas Esa Unggul \\ Email: mujazi@esaunggul.ac.id
}

\begin{tabular}{|c|c|}
\hline \multicolumn{2}{|c|}{ Artikel info } \\
\hline \multicolumn{2}{|c|}{ Artikel history } \\
\hline Diterima & : 16-11-2020 \\
\hline Direvisi & : 20-12-2020 \\
\hline Disetujui & $: 25-12-2020$ \\
\hline
\end{tabular}

Kata kunci: Penggunaan STAD, Aktifitas Belajar, Hasil belajar

Keywords: Use of STAD, Learning Activities, Learning Outcomes

\begin{abstract}
Abstrak
Penelitian ini bertujuan mengimplementasikan metode Student Teams Achievement Division (STAD) untuk meningkatkan aktivitas dan hasil belajar peserta didik mata pelajaran Sosiologi sub pokok bahasan diferensiasi sosial tahun pelajaran 2019/2020. Metode penelitian ini menggunakan penelitian tindakan kelas, meliputi perencanaan, tindakan, pengamatan, dan refleksi. Subjek penelitian ini adalah siswa kelas XI. IPS SMA Al-Mubarok Kota Tangerang berjumlah 24 siswa. Penelitian meliputi pra penelitian, siklus I, dan siklus II. Data penelitian diperoleh menggunakan lembar observasi aktivitas siswa, wawancara guru mata pelajaran, dan tes hasil belajar. Teknik yang digunakan untuk menganalisis data adalah teknik deskriptif (rata-rata dan persentase). Hasil penelitian ini menunjukkan adanya peningkatan persentase aktivitas dan hasil belajar siswa kelas pada setiap siklus. Ketuntasan aktivitas belajar pada pra penelitian $42 \%$, siklus I $60 \%$ dan siklus II menjadi $80 \%$. Untuk ketuntasan hasil belajar pra siklus nilai rata-rata $62.08(33.3 \%)$, siklus I nilai rata-rata $68.79(62.5 \%)$, dan siklus II nilai rata-rata $79.38(83.3 \%)$.
\end{abstract}

\section{Abstract}

This study aims to implement the Student Teams

Achievement Division (STAD) method to improve the activities and learning outcomes of students in Sociology subjects sub- subject of social differentiation in the 2019/2020 school year. This research method uses class action research, including planning, action, observation, and reflection. The subject of this study was grade XI students. Ips Sma AlMubarok Tangerang city numbered 24 students. The research includes preresearch, cycle I, and cycle II. The research data were obtained using student activity observation sheets, subject teacher interviews, and learning outcome tests. The technique used to analyze the data is a descriptive technique (average and percentage). The results of this study showed an increase in the rate of activities and learning outcomes of class students in each cycle. Completeness of learning activities in pre-research $42 \%$, cycle I $60 \%$ and cycle II to $80 \%$. For the completeness of pre-cycle learning results an average score of 62.08 (33.3\%), cycle I averaged 68.79 (62.5\%), and cycle II averaged $79.38(83.3 \%)$..

Koresponden author: Mujazi Email: mujazi@esaunggul.ac.id artikel dengan akses terbuka dibawah lisensi CC BY SA 2020

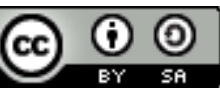

\section{Pendahuluan}

Pendidikan saat ini hendaknya didasarkan pada kualitas dan kemampuan pendidik yang menggunakan metode ini, yaitu guru menggunakan berbagai metode pembelajaran yang 
ada untuk menyelesaikan permasalahan yang ada, terutama yang dihadapi oleh siswa. Penerapan metode pembelajaran yang tidak tepat dapat menimbulkan kebosanan, pemahaman yang buruk dan monoton sehingga mengurangi aktivitas belajar siswa (Prasetyaningtyas, n.d.). Guru harus mempersiapkan mata pelajaran yang membangkitkan semangat dan membuat mereka berpikir lebih aktif, positif, kritis dan kreatif. Belajar langsung dari guru melalui pengajian, dan fokus hanya pada isi saja tidak dapat melatih siswa dalam segala aspek (Tiantong, M., \& Teemuangsai, 2013).

Berdasarkan hasil wawancara dengan guru Sosiologi di SMA Al Mubarok ditemukan bahwa pada kenyataannya guru sedang menghadapi kendala dan kesulitan dalam mengajar di kelas, untuk itu perlu dicari solusinya. Hambatan dan kesulitan tersebut berupa kurangnya sarana dan prasarana penunjang kegiatan mengajar, sehingga siswa jarang melakukan percobaan atau percobaan. Siswa memiliki aktivitas belajar yang kurang, seperti kurang membaca, kurang perhatian, semangat kerja rendah, dan aktivitas kurang. Kegiatan belajar mengacu pada kegiatan fisik dan mental. Kedua aktivitas ini saling terkait (Sardiman, 2011). Selain kegiatan pembelajaran, guru juga mengakui bahwa penggunaan metode pembelajaran masih rutin, asalkan topiknya hanya bersifat eksplanatif atau instruktif. Ini berdasarkan opini (Esminarto et al., 2016) Beberapa guru lebih suka menggunakan metode pembelajaran tradisional, asalkan informasinya satu arah dan siswa adalah penerima atau pendengar pasif dari informasi tersebut. Hasil studi pendahuluan menunjukkan bahwa nilai siswa terendah 30 dan nilai tertinggi 75. KKM sekolah 75, nilai ketuntasan rata-rata 62,5, dan ketuntasan belajar hanya 8 siswa (33,3\%). Ini sesuai dengan penelitian (Kalim, 2013) Terlihat bahwa rata-rata prestasi akademik siswa adalah 66,3, dan tingkat ketuntasan belajar mencapai 45\%, atau 17 dari 38 siswa yang tuntas pada siklus I siklus III.

Berdasarkan fakta tersebut, proses pembelajaran perlu diubah atau ditingkatkan. Hal tersebut perlu dilakukan untuk meningkatkan aktivitas belajar siswa. Guru perlu memahami metode pembelajaran agar dapat beroperasi secara efektif. Dalam penggunaannya, metode pembelajaran harus dilaksanakan sesuai dengan kebutuhan siswa, karena setiap metode pembelajaran memiliki tujuan, prinsip dan tekanan utama yang berbeda (Esminarto et al., 2016). Pembelajaran kooperatif merupakan salah satu metode pembelajaran yang menuntut antusiasme siswa. Pembelajaran kooperatif merupakan strategi pengajaran yang menuntut siswa untuk bekerja sama untuk mencapai tujuan bersama. Hal senada diungkapkan Aidu 
(Karacop, 2016) Pembelajaran kooperatif merupakan salah satu metode pembelajaran aktif yang paling umum digunakan dalam pembelajaran akhir-akhir ini.

Pembelajaran kooperatif merupakan pembelajaran kelompok yang dilaksanakan secara bersama-sama.Setiap anggota bertanggung jawab atas pelaksanaan pembelajaran dan bertujuan untuk meningkatkan pembelajaran anggota kelompok lainnya (Huda, 2013, p. 110). Johnson et al. dalam (Wyk, 2012) Pembelajaran kooperatif secara tertulis tidak hanya identik dengan kerjasama tim, tetapi juga tidak hanya melibatkan siswa yang bekerja sama dalam sebuah tim. Menurut (Isjoni, 2011) Pembelajaran kooperatif adalah strategi pengajaran praktis yang bertujuan untuk memberikan siswa pengalaman belajar yang lebih positif, kesempatan belajar yang setara dan lingkungan sosial yang lebih baik. Tujuan penggunaan metode pembelajaran kooperatif dalam kegiatan mengajar adalah agar siswa berani mengungkapkan pendapat, gagasan dan sikap saling menghargai dalam kelompok. Siswa harus memverifikasi pendapat orang lain dan mengevaluasi pemahaman teman sebayanya, dan merangkum konsep yang dikontribusikan oleh setiap siswa (Yeung, 2015).

Penilaian akan menilai pemahaman mereka tentang ide-ide kunci melalui demonstrasi, kuis, dan aplikasi. Kemajuan siswa akan diukur dengan skor yang dikumpulkan. Banyak karakteristik STAD adalah pembelajaran yang bermanfaat, tanggung jawab pribadi, tekanan teman sebaya, saling ketergantungan anggota kelompok, evaluasi berkelanjutan, dan bentuk penghargaan atas hasil pembelajaran (Khan \& Inamullah, 2011). Beberapa hal yang diamati selama proses observasi adalah pelaksanaan tahapan-tahapan penggunaan metode pembelajaran kooperatif STAD meliputi presentasi kelas, belajar kelompok, kuis, peningkatan nilai individu dan reward kelompok (Slavin, 2015). Sementara (Esminarto et al., 2016) Menulis, hasil belajar siswa mengalami peningkatan karena metode pembelajaran kooperatif tipe STAD merupakan salah satu upaya guru untuk mewujudkan pemahaman konseptual dan mendorong siswa untuk aktif bertukar pikiran dan memahami topik satu sama lain, yang dapat meningkatkan hasil belajar siswa. Penelitian (Ramafrizal \& Julia, 2018) Tunjukkan bahwa pembelajaran tipe STAD dapat berperan dalam proses pengajaran lanjut (Astiti, n.d.) mengatakan ada perbedaan aktifitas dan prestasi belajar antara siswa yang menggunakan tipe STAD dengan pembelajaran konvensional. Selanjutnya (Kalim, 2013) menyatakan model pembelajaran tipe STAD berpengaruh meningkatkan motivasi siswa dalam belajar.

Berdasarkan pandangan di atas, penelitian kolaboratif tipe STAD hanya mempunyai satu masalah yaitu hasil belajar, perbedaan dan motivasi. Akan tetapi, kegiatan belajar dan hasil belajar jarang dipelajari secara bersamaan. Oleh karena itu, judul penelitian ini adalah: "Menggunakan metode pembelajaran kooperatif tipe STAD untuk meningkatkan aktivitas belajar dan hasil belajar siswa".

Menanggapi permasalahan diatas maka tujuan penelitian ini adalah untuk memahami dan menguji penggunaan metode pembelajaran STAD dalam meningkatkan aktivitas dan hasil belajar siswa. Penelitian ini diharapkan dapat membantu guru menguasai lebih banyak metode pembelajaran daripada hanya terbatas pada satu metode pembelajaran. Harapan siswa meningkatkan aktivitas dan hasil belajarnya.

\section{Metode Penelitian}

Penelitian ini merupakan penelitian tindakan kelas. Berencana melakukan penelitian tindakan dengan menggunakan metode pembelajaran kooperatif STAD dalam pembelajaran 
sosiologis dalam diskusi referensi sosial. Penelitian dilakukan di SMA Al-Mubarok Kota Tangerang Provinsi Banten. Penelitian dilakukan mulai Januari hingga Februari 2020. Objek penelitian dalam penelitian ini adalah kategori XI. IPS memiliki 24 orang. Data penelitian meliputi data primer dan data sekunder. Data utama diperoleh melalui observasi, wawancara, dokumen dan tes hasil belajar. Pada saat yang sama, data pembantu diperoleh melalui literatur atau laporan penelitian. Teknik pengumpulan data dilakukan di lokasi penelitian melalui observasi, wawancara, dokumentasi dan anotasi. Pelaksanaan kegiatan diawali dengan perencanaan, pelaksanaan, observasi dan refleksi. Setelah sekolah memahami dan menyelesaikan masalah, maka dimulai rencana tindakan. Kemudian peneliti melakukan kegiatan pembelajaran sesuai RPP sekaligus mengamati kegiatan pembelajaran tersebut. Langkah-langkah penggunaan metode pembelajaran kooperatif tipe STAD meliputi 6 langkah, meliputi: (1) pengelompokan, (2) pemberian informasi; (3) diskusi; (4) pertanyaan atau kuis; (5) penarikan kesimpulan dan (6) pemberian reward (Wibowo, 2013). Selama penelitian, observasi dilakukan sesuai dengan formulir observasi dan pedoman wawancara.

Penelitian dilaksanakan dalam dua siklus, dengan 2 kali pertemuan di setiap siklus. Teknik pengumpulan data dilakukan melalui wawancara, pencatatan, observasi, dan tes hasil belajar. Analisis data dalam penelitian tindakan ini dilakukan secara kualitatif. Analisis data dilakukan dengan menganalisis data kualitatif yang diperoleh dari wawancara, kemudian dideskripsikan dalam bentuk deskripsi naratif untuk mendeskripsikan situasi pembelajaran. Pada akhir siklus I dan II dilakukan tes hasil belajar berupa data kuantitatif. Bentuk analisis statistik deskriptif meliputi skor rata-rata (rata-rata), ketuntasan kegiatan belajar dan hasil belajar.

Indikator keberhasilan penelitian ini: (1) Siswa yang telah mencapai nilai minimal 80\% sesuai standar sekolah; (2) Rata-rata hasil belajar siswa tingkat XI dan IPS pada mata pelajaran sosiologi minimal 75; (3) Aktivitas belajar siswa dalam pembelajarannya Setidaknya $75 \%$, kisarannya $0-100 \%$.

\section{Hasil dan Pembahasan}

\section{Aktivitas Belajar}

Kegiatan observasi adalah observasi aktivitas belajar siswa dalam proses pembelajaran dengan menggunakan pedoman observasi yang telah disediakan. Kegiatan observasi ini dilakukan dengan cara mengamati aktivitas belajar siswa selama proses pembelajaran. Selain itu, observasi dianalisis untuk mengetahui persentase aktivitas belajar siswa. Gambar di bawah ini menunjukkan hasil analisis kegiatan belajar siswa putaran sebelumnya, putaran pertama dan putaran kedua. 


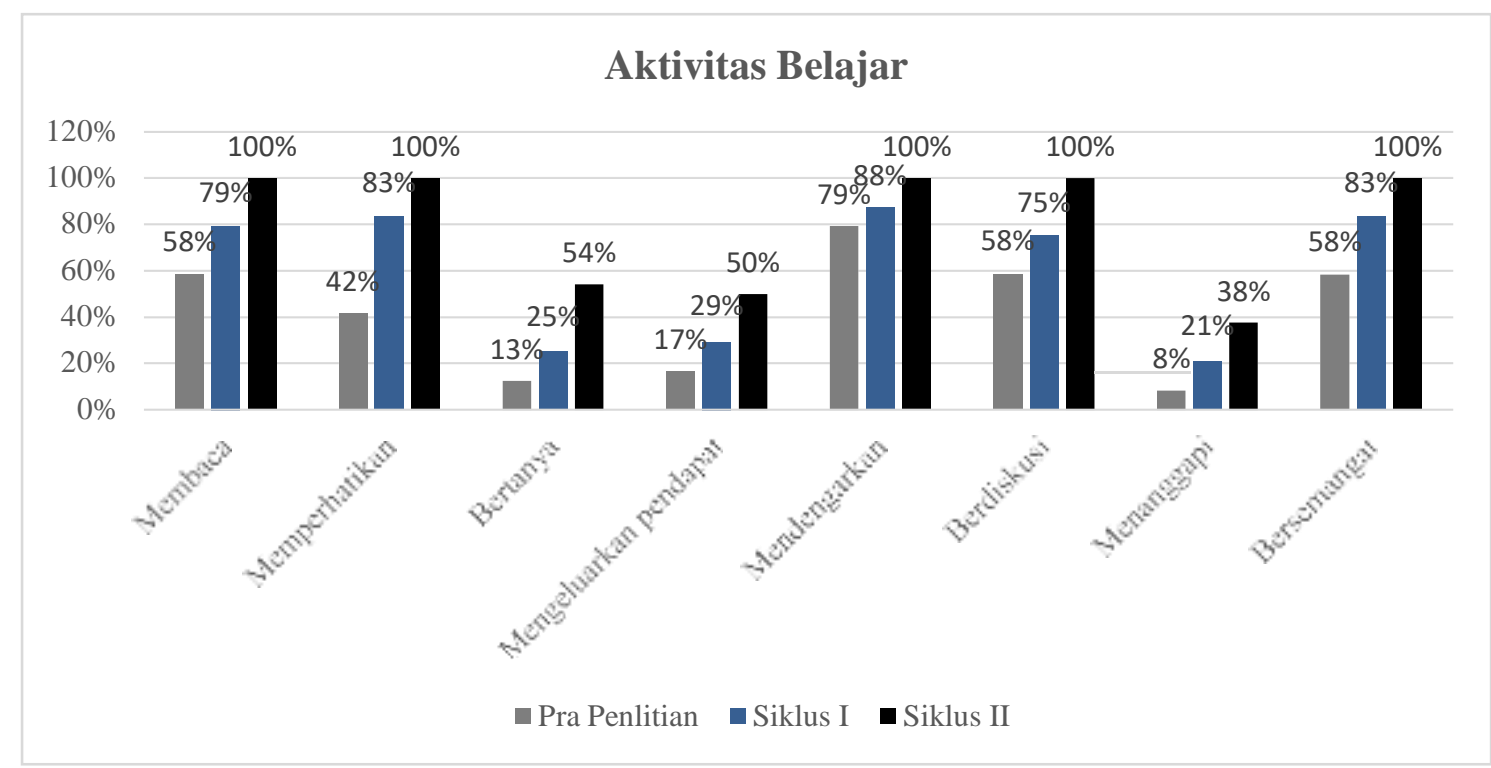

Gambar 1. Diagram Rekapitulasi Aktivitas Belajar

Hal ini dapat dilihat dari Gambar 1 bahwa pada pembelajaran pra penelitian aktivitas belajar (aktivitas visual) siswa dengan indikator membaca adalah 58\% yang meningkat menjadi $79 \%$ pada siklus I dan $100 \%$ pada siklus II atau semua siswa. Baca keduanya. Untuk indikator perhatian (aktivitas visual), sebanyak $42 \%$ siswa memperhatikan pra penelitian, meningkat menjadi $63 \%$ pada siklus I dan $100 \%$ pada siklus II, atau semua siswa memperhatikan presentasi guru atau berteman. . Pada prapembelajaran, hanya $13 \%$ siswa bertanya atau bertanya (kegiatan lisan), yang meningkat menjadi $25 \%$ di babak pertama dan $54 \%$ di babak kedua. Ini adalah pertumbuhan yang sangat penting dan sudah mulai berani bertanya. Pada studi pra studi, indikator untuk mengungkapkan pendapat (oral activity) adalah $17 \%$, meningkat menjadi $29 \%$ pada siklus I dan $50 \%$ pada siklus II. Hal ini menunjukkan bahwa telah terjadi peningkatan yang cukup besar, dan keberanian siswa mulai terlihat untuk menjawab pertanyaan yang diberikan. Indikator pendengaran (auditory activity) pada pra studi mencapai $79 \%$, meningkat menjadi $88 \%$ pada siklus I dan $100 \%$ pada siklus II. Hal ini menunjukkan bahwa siswa sudah mulai mengapresiasi dan fokus pada semua konten yang dijelaskan, dan mulai mengapresiasi lawan bicara. Kategori diskusi (kegiatan menyimak) pada prastudi studi sebesar $58 \%$, meningkat menjadi $75 \%$ pada siklus I, dan $100 \%$ pada siklus II. Pada pra penelitian kategori respon terhadap opini (aktivitas mental) sebesar $8 \%$ meningkat menjadi $17 \%$ pada siklus I dan $33 \%$ pada siklus II. Pada prastudi kategori kegembiraan (aktivitas emosional) meningkat sebesar 58\%, meningkat menjadi $83 \%$ pada siklus I, dan meningkat menjadi $100 \%$ pada siklus II. 


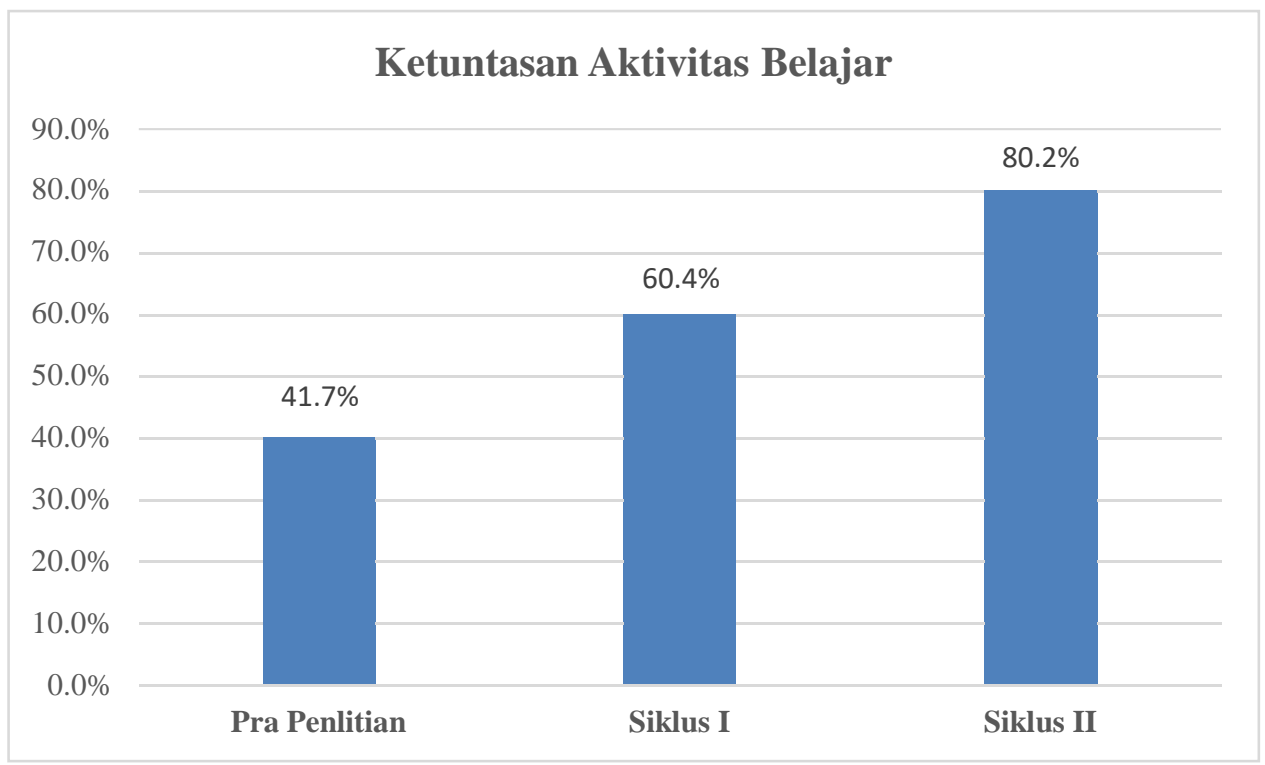

Gambar 2. Diagram persentase ketuntasan aktivitas belajar

Berdasarkan Gambar 2 di atas, hasil prastudi menunjukkan bahwa tingkat aktivitas belajar siswa kelas XI.IPS sebenarnya adalah 24 siswa dalam standar sedang (yaitu 41,7\%), tetapi standar yang ditetapkan sekolah masih $75 \%$. Sebagian besar observasi siswa kurang aktif dalam kegiatan pembelajaran. Siswa ingin menjawab setelah ditunjuk, bahkan sering diam. Beberapa siswa di barisan belakang masih sibuk dengan aktivitasnya. Siswa masih kurang antusias mendengarkan penjelasan guru. Guru masih menggunakan metode ceramah untuk meningkatkan perhatian siswa pada buku teks yang sedang berjalan.

Selain itu, hasil observasi pada siklus I ditemukan bahwa tingkat aktivitas belajar siswa meningkat sebesar $60,4 \%$. Persentase aktivitas siswa masih di bawah $75 \%$ standar yang ditetapkan sekolah. Menurut observasi babak pertama, siswa sangat antusias dalam proses pembelajaran. Mahasiswa juga aktif mempresentasikan hasil diskusi. Namun siswa belum aktif menjawab pertanyaan guru, bereaksi terhadap masalah yang dihadapi dan membantu teman yang bermasalah. Dalam proses pembelajaran, siswa seringkali bersifat pasif. Masih ada siswa yang kurang memperhatikan materi yang dikenalkan oleh guru. Ketika dibagi ke dalam kelompok, siswa akan memilih teman daripada menggunakan model pembelajaran kooperatif STAD untuk pembelajaran. Kerja sama siswa dalam kelompok masih minim materi pembelajaran, dan masih ada anggota kelompok yang kurang aktif dalam diskusi dan diskusi individu. Pada pertemuan pertama, siswa terlihat tidak aktif dan kebingungan dalam proses pembelajaran. Hal ini dikarenakan siswa masih merasa awam dan kurang memahami makna dan tujuan guru melalui penerapan metode pembelajaran kooperatif tipe STAD. Beberapa siswa asyik berbicara dengan teman sebayanya. Namun setelah dihubungi dan diperingatkan, para siswa akan kembali ke mata kuliah dengan serius. Secara umum dibandingkan dengan siswa sebelum menerapkan model pembelajaran kooperatif tipe STAD, perhatian, antusiasme dan kerjasama siswa cukup baik.

Setelah siklus II, peneliti mengamati bahwa aktivitas belajar siswa meningkat dari $60,4 \%$ pada siklus I menjadi $80,2 \%$ pada siklus II. Meningkat 19,8\%. Setelah pembelajaran mata kuliah peningkatan aktivitas belajar siswa terlihat lebih antusias, dan saat peneliti melakukan kegiatan pra penelitian situasinya agak berbeda. Pada pembelajaran siklus kedua, siswa terlihat sangat aktif dalam proses pembelajaran. Hal ini dikarenakan siswa sudah mulai 
beradaptasi dan memahami metode pembelajaran kooperatif tipe STAD yang diterapkan. Secara umum perhatian, antusiasme dan kerjasama siswa lebih baik dibandingkan observasi putaran pertama. Siswa terlihat lebih antusias, jika pembahasan tidak dipahami siswa tidak akan lagi bertanya dengan malu-malu, jika ada pendapat dari teman yang berbeda, mereka berani mengutarakan pendapatnya. Hasil penelitian menunjukkan bahwa sesuai dengan hasil penelitian mahasiswa sangat antusias terhadap model pembelajaran segmen prestasi tim mahasiswa (Syahidi \& Asyikin, 2018) dan (Ningtias \& Handayani, t.t.).

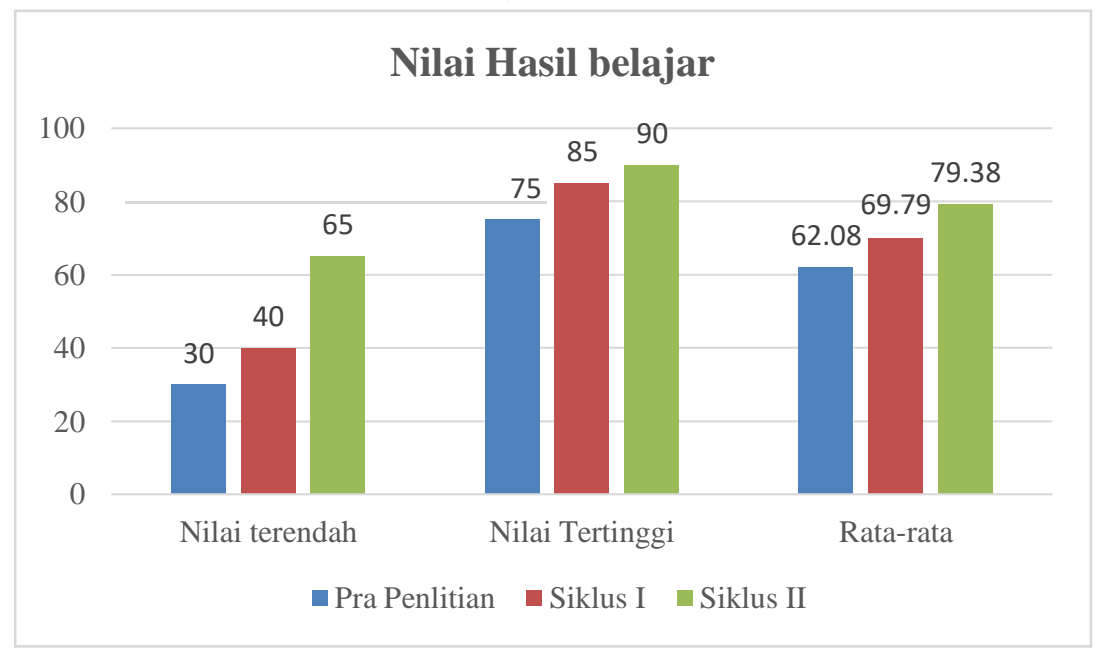

Gambar 3. Diagram Nilai Hasil Belajar

Pada Gambar 3 di atas, diketahui bahwa nilai siswa meningkat dari nilai terendah, tertinggi dan rata-rata. Pada studi pra penelitian, nilai minimal siswa hanya 30, meningkat menjadi 40 di babak pertama dan 60 di babak kedua. Nilai tertinggi juga meningkat dari 75 sebelum penelitian. Standar integritas minimal untuk SMA Al-Mubarok adalah 75. Pada siklus I skor meningkat menjadi 80, dan siklus II skor meningkat menjadi 90. Nilai rata-rata siswa mengalami peningkatan dibandingkan sebelum pembelajaran yaitu rata-rata 62.08 meningkat menjadi 69.79. Meskipun rata-rata hasil belajar pada siklus II sebesar 79,38 namun telah melebihi nilai KKM yang ditetapkan 75 sekolah. Berdasarkan hal tersebut maka dapat dikatakan bahwa dengan menggunakan metode pembelajaran tipe STAD dapat meningkatkan hasil belajar siswa.

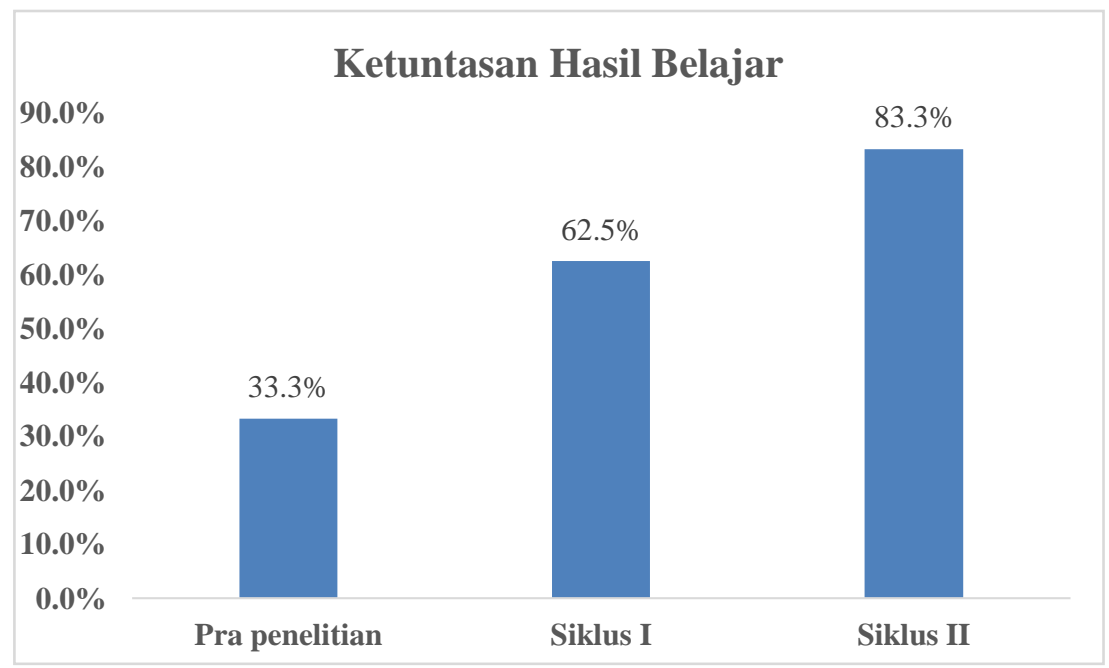

Gambar 3. Diagram persentase ketuntasan belajar 
Berdasarkan Gambar 4 di atas, pada studi prapenelitian ditemukan bahwa hasil belajar dari proses pembelajaran sosiologi tergolong belum tuntas.Dari evaluasi hasil belajar, hanya 8 siswa $(33,3 \%)$ yang tuntas. Namun pada siklus I persentase ketuntasan hasil belajar sejarah siswa lebih tinggi dibandingkan pada siklus pra penelitian. Pada hasil belajar terdapat 15 siswa dengan skor $\geq 75$ terhitung $62,5 \%$ dan hanya 9 siswa dengan skor $<75$ terhitung $37,5 \%$. Pada pra penelitian dan pembelajaran putaran pertama persentase hasil belajar siswa secara tradisional dianggap tidak tuntas dan tergolong "kurang" karena sekolah memutuskan untuk menyelesaikan ketuntasan hasil belajar, karena siswa yang mencapai atau melebihi 75 adalah $2075 \%$ dari siklus. Persentase wa $83,3 \%$, sedangkan hanya 4 siswa yang mendapat nilai di bawah 75 yaitu $16,7 \%$.

Berdasarkan analisis data yang diperoleh, dari periode I ke periode I aktivitas belajar siswa dan hasil belajar siswa kelas XI.IPS SMA Al-Mubarok mengalami peningkatan dari periode I ke periode II. Hal ini membuktikan bahwa metode pembelajaran kooperatif tipe STAD dapat meningkatkan aktivitas belajar siswa dan hasil belajar sosiologi siswa kelas XI IPS SMA Al-Mubarok Kota Tangerang. Siswa memiliki pandangan yang sangat positif tentang pembelajaran dengan STAD. Hal ini menunjukkan bahwa siswa lebih semangat, semangat dan senang dalam belajar. Proses pembelajaran dimulai dengan demonstrasi, pembentukan kelompok, penilaian kemajuan dan penghargaan. Tuturan guru menuntut siswa untuk lebih memperhatikan, berani bertanya, mengutarakan pendapat, dan berani menanggapi pendapat teman. Tujuan dari belajar kelompok adalah untuk mengatasi masalah pada LKS secara bersama-sama dalam kelompok. Karena belajar kelompok akan mendorong siswa untuk mengemukakan ide-idenya sendiri untuk menyelesaikan masalah di LKS. Tujuan tes adalah untuk mengetahui tingkat pemahaman siswa terhadap materi penelitian. Memberikan reward atau reward agar siswa lebih bersemangat mengikuti kuis untuk mendapatkan nilai terbaik. Menurut (Kimmelmann \& Lang, 2019) dari sudut pandang guru dan siswa, banyak manfaat yang didapat dari pembelajaran kooperatif dengan guru menggunakan metode STAD.

\section{Kesimpulan}

Berdasarkan analisis hasil penelitian dan pembahasan dapat disimpulkan bahwa pembelajaran kelompok merupakan pembelajaran terhadap permasalahan pada LKS, dan dapat disimpulkan bahwa penggunaan metode pembelajaran kooperatif pada mata pelajaran prestasi tim siswa pada mata pelajaran sosiologi dapat meningkatkan. Kegiatan belajar dan prestasi belajar sejarah siswa XI. Pelajaran IPS SMA Al-Mubarok Tangerang bahkan semester tahun ajaran 2019/2020 dijabarkan secara rinci sebagai berikut: (1) Pada kelas XI IPS SMA Al-Mubarok 2019/2020, penggunaan metode pembelajaran kooperatif tipe STAD dapat meningkatkan aktivitas pembelajaran sosiologis siswa. Pada studi pra penelitian, aktivitas belajar siswa biasanya 33,33\% termasuk dalam kategori miskin. Pada siklus I aktivitas belajar siswa biasanya meningkat menjadi 46,83\% termasuk kategori cukup baik. Pada tahap kedua aktivitas belajar siswa meningkat menjadi 78,65\% dengan kategori baik.

(2) Dengan menggunakan model pembelajaran kooperatif tipe tim siswa jurusan XI, ketuntasan hasil belajar sosiologi telah ditingkatkan. Ilmu Sosial SMA Al-Mubarok tahun ajaran 2019/2020. Sebelum siklus ketuntasan hasil belajar kognitif klasikal siswa sebanyak 8 
siswa $(33,3 \%)$. Pada siklus I hasil belajar meningkat menjadi $62,5 \%$. Pada siklus II prestasi belajar juga meningkat menjadi $83,3 \%$.

\section{Bibliography}

Astiti, N. W. (n.d.). Pengaruh Model Pembelajarn Kooperatif Tipe STAD dan Motivasi Prestasi Terhadap Hasil Belajar IPS Siswa Kelas VII SMP Negeri 2 Semarapura. 14.

Esminarto, E., Sukowati, S., Suryowati, N., \& Anam, K. (2016). Implementasi Model STAD Dalam Meningkatkan Hasil Belajar Siswa. Briliant: Jurnal Riset dan Konseptual, 1(1), 16. https://doi.org/10.28926/briliant.v1i1.2

Huda, M. (2013). Model-Model Pengajaran dan Pembelajaran (Cetakan III). Pustaka Pelajar.

Isjoni. (2011). Pembelajaran kooperatif meningkatkan kecerdasan komunikasi antar peserta didik. Pustaka Pelajar.

Kalim, N. (2013). (Cooperative learning model stad to improve mathematics result). 8.

Karacop, A. (2016). Effects of Student Teams-Achievement Divisions Cooperative Learning with Models on Students' Understanding of Electrochemical Cells. International Education Studies, 9(11), 104. https://doi.org/10.5539/ies.v9n11p104

Khan, G. N., \& Inamullah, H. M. (2011). Effect of student's team achievement division (STAD) on academic achievement of students. Asian Social Science, 7(12), 211-215.

Kimmelmann, N., \& Lang, J. (2019). Linkage within teacher education: cooperative learning of teachers and student teachers. European journal of teacher education, 42(1), 52-64.

Prasetyaningtyas, S. (n.d.). Penerapan Model Pembelajaran Koperatif Stad Untuk Meningkatkan Keaktifan dan Prestasi Belajar IPA Pada Materi Pewarisan Sifat Siswa Kelas IX SMP Negeri 1 Semin. 13.

Ramafrizal, Y., \& Julia, T. (2018). Kajian Model Pembelajaran Kooperatif Tipe STAD (Student Teams Achievement Division) Dalam Upaya Meningkatkan Efektifitas Proses Belajar Mengajar Akuntansi. OIKOS Jurnal Kajian Pendidikan Ekonomi dan Ilmu Ekonomi. https://doi.org/10.23969/oikos.v2i2.1049

Sardiman. (2011). Interaksi dan motivasi belajar mengajar. Jakarta: Raja Grafindo Persada.

Slavin, R. E. (2015). Cooperative learning in schools. Dalam International Encyclopedia of the Social \& Behavioral Sciences (hlm. 881-886). Elsevier. https://doi.org/10.1016/B978-0-08-097086-8.92028-2

Syahidi, A. A., \& Asyikin, A. N. (2018). Applying Student Team Achievement Divisions (STAD) Model on Material of Basic Programme Branch Control Structure to Increase Activity and Student Result. IOP Conference Series: Materials Science and Engineering, 336(1), 12027. 
Tiantong, M., \& Teemuangsai, S. (2013). Student Team Achievement Divisions (STAD) Technique through the Moodle to Enhance Learning Achievement. International Education Studies, 6(4).

Wibowo, R. (2013). PENERAPAN MODEL KOOPERATIF TIPE STAD DALAM PENINGKATAN PEMBELAJARAN BANGUN DATAR PADA SISWA KELAS V SD. KALAM CENDEKIA PGSD KEBUMEN, 5(1).

Wyk, M. M. van. (2012). The Effects of the STAD-Cooperative Learning Method on Student Achievement, Attitude and Motivation in Economics Education. Journal of Social Sciences, 33(2), 261-270. https://doi.org/10.1080/09718923.2012.11893104

Yeung, H. C. H. (2015). Literature review of the cooperative learning strategy-student team achievement division (STAD). International Journal of Education, 7(1), 29-43. 